\title{
Dracula's Brides: Economic Seclusion, Prostitution, and Domestic Neglect
}

\section{Abriel Garrick}

\begin{abstract}
Bram Stoker's Dracula accrued international recognition and acclaim and is the foundation of an expansive creative outpour of literature, film adaptations, and numerous interpretations. The name Dracula is familiar around the world and has been critiqued by numerous schools of thought. The paper looks at the Bram Stoker's use of female vampires to highlight the New Woman, economic dependence, and domestic neglect.
\end{abstract}

Keywords--Domestic, New Woman, vampire, Victorian

Bram Stoker's Dracula was written in the midst of intense social uproar; the New Woman fueled anxiety toward changing gender roles in Victorian era England; progressive women struggled for social equality and against the negative impact of stagnant social expectations. The restrictive gender roles in Victorian England kept women secluded to their homes. Thought of as delicate and fragile, women needed protection from the complications of society. Thought of as a means of protection, women's restriction to the home became a hindrance to their social progress. By restricting Dracula's brides to his castle, Stoker highlights women's immobility and subsequent dependence on the males in their family. Bram Stoker uses Dracula's brides' restricted domain to highlight the limited opportunities for women to progress outside of their economic gender roles. Women who did venture beyond the hearth were thought to have 'abandoned' their domestic duties, allowing the societal influence to penetrate the home, and disturbing the atmosphere of respite in the home.

While in Castle Dracula Jonathan Harker witnesses the physical restrictive aspects of the female vampires' surroundings. Dracula has placed his brides' quarters in the most secure position;

From the windows I could see that the suite of rooms lay along to the south of the castle, the windows of the end room looking out both west and south. On the latter side, as well as to the former, there was a great precipice. The castle was built on the corner of a great rock, so that on three sides it was quite impregnable, and great windows were placed here where sling, or bow, or culverin could not reach, and consequently light and comfort, impossible to a position which had to be guarded, were secured. To the west was a great valley, and then, rising far away, great jagged mountain vastnesses, rising peak on peak, the sheer rock studded with mountain ash and thorn, whose roots clung in cracks and crevices and crannies of the stone. This was evidently the portion of the castle occupied by the ladies in bygone days, for the furniture had more an air of comfort than any I had seen. (35)

Initially meant for protection from hostile society, the impenetrable fortress is now a controlled prison. The same security against the dangerous outside world is a prison limiting their interaction and influence on the larger society. The women's suite was positioned where the natural terrain would not allow outside guidance to reach Dracula's brides.

Women's 'occupation' of wife and mother left their financial security solely reliant on the men in their lives. Women's intellectual, physical, and rational abilities were measured against their proficiency in their domestic duties. The long held belief that women belonged by the hearth was based on their perceived inherent qualities. Women's ability to perform adequately in occupations outside the home was seen as non-existent because the effort needed was too rigorous. To break the cycle of dependence upon men new employment opportunities were needed; better employment required better education. In "Feminist Thinking on Education in Victorian England" Laura Schwartz asserts:

Opposition to women's education was based upon a strong assertion of sexual difference . . . women's intellects were seen as insightful and sensitive without the ability to make rational evidence-based judgements; physiologically, they were not equipped to deal with the rigours of university education . . . because women's vocation in life was supposedly different from that of men, it was believed to be pointless and cruel to educate her beyond her sphere as wife and mother. (674)

Without skills to earn a living outside of their sexual qualities women whom desired to maintain economic autonomy turned to the reliable profession open to women; prostitution. 
The female vampires' dependence on Dracula represents not only a dominating patriarch but also highlights society's subjugation and lack of options for financial security for women. This circumstance was present throughout history which often forced women into domesticity or prostitution. Just as Dracula's female vampires were forced into becoming fallen, without education women's employment opportunities were scarce and many turned to prostitution to support themselves.

In "Help to the Fallen" published 1859, Robert and William Chambers outline the perpetual cycle the lower classes are fixed and thus: "are educated perforce-by Necessity as well as by Father and Mother-in thieving and debauchery; are brought up to the profession of Crime . . . they will have committed no real crime at all, but only a necessity, discountenanced, for very sufficient reasons, by the law of the land" (original emphasis, 11).

As Brynne points out in his 1888 article "Women and their Sphere" the only reliable occupations for Victorian women were wife or prostitute:

Primarily, the value of women to men is their sexual value, their value as workers being a very secondary matter; whereas, primarily, the value of men to women is their capacity and power for work and defense, their sexuality being but secondary . . . the wages of all women are conditioned by their sexual resources; their sexuality is a saleable thing; marriage or prostitution is open to all, and a reserve fund being thus established in fact, their honest wages suffer. (original emphasis 6-7)

In "Feminist Thinking on Education in Victorian England" Laura Schwartz asserts: "Elizabeth Wolstenholme protested that 'It is to the last degree indecent that women should be dependent upon marriage for a professional maintenance' (Wolstenholme, 1869, p. 318) . . . Without adequate training or employment, middle-class women were forced into low-paid positions of "drudgery" (673).

Mirroring Victorian England's slums where, as Chambers and Chambers puts it: "the Dangerous Classes grow up, all by themselves, in filthy sties . . . are born and bred every year in an atmosphere of temptation and ignorance such as honesty cannot draw breath in" (11).

The ideal feminine wife and mother was a nonsexual person; the over-sexualizing of Dracula's brides leaves prostitution as an acceptable interpretation. The oversexualizing attributed to Dracula's brides is a forced characteristic they received with the vampire's curse. This forced sexualizing represents the lower class women's necessity to become over-sexualized as prostitutes. Without an alternative, women turned to prostitution to support themselves Just as Dracula's female vampires are forced into becoming fallen and have no alternative to survive women without education or employable skills compulsory turned to prostitution.

The inference is given further weight once Van Helsing is able to end their 'lives' and the female vampires have a relief that comes over them; they are freed of an existence they did not choose but were forced into. As Jennifer A. Swartz-Levine points out in "Staking Salvation: The Reclamation of the Monstrous Female in Dracula": "The creatures do not get to be female until after Van Helsing destroys them. They are a collective 'it' until after 'the soul had been won' at which point they become 'them' and 'her"' (357). He is separating the women under the seductive vampires from the collective 'fallen woman' and 'prostitute' label; restoring their nonsexual femininity. Just before they turn to dust they have a look of "repose . . . gladness . . . the realization that the soul had been won" (359) as they are being spared their continued involvement in vampirism (prostitution) and over-sexualization they were forced into.

Harker's vague recollection of the female vampires, his fear, and his "burning desire that they would kiss me with those red lips" (37) is description of the English prostitutes. The vague recognition, sexualizing, longing, and fear, of the vampires are the same hidden and unspoken societal dynamics of prostitutes in the Victorian era.

The female vampires are shut in their bedrooms; only making an appearance when sought out. Their further seclusion to their prescribed domain in the shadows, only materializing at night, mirrors prostitutes' 'work' schedule. Prostitutes are 'women of the night' consolidated and working in specific areas of the city. Carrol L. Fry states in "Fictional Conventions and Sexuality in Dracula";

In fiction, it is conventional for the fallen woman to become an outcast, alienated from the rest of mankind, or to die a painful death. If she lives, she often becomes a prostitute or the chattel of her seducer. . . Similarly, Dracula's castle is occupied by his 'wives,' who were at some earlier time his victims. . . He has loved them with the vampire's phallic bite, and they have become outsider, UnDead, and, like the fallen woman, not part of the human race. (21)

The difficulty in maintaining independence in the Victorian Era's gender debate was not hidden from social consciousness. Women's struggle to maintain independence 
did not gain sympathy from all observers. In "On Some Economic Aspects of Women's Suffrage" R.B. Haldane relates the damages women's economic progression for men and themselves:

The grim spectacle of tens of thousands of women struggling to keep body and soul together under circumstances of misery; too thankful if they can gain the privilege of working for fifteen or sixteen hours a day for the starvation wages which represent the market rate. And yet population ought not to press in this case more hardly on the means of subsistence than it does in that of men ... and if to purchase the needed reform the finer graces of a handful of fine ladies have to go by the board, they must just do so. (834)

As Haldane shows, men were willing to circumvent any advance in women's economic equality for the 'greater good' of men's wages. Believing that women's employment deterred union advancements for fair wages, men were willing to sacrifice women's right to work, and call them to do the same, to maintain men's wages; declaring "they must just do so" (834).

Resistance to opening employment opportunities to women from male society left two timeless occupations open to women; wife and prostitute. As Swartz-Levine points out:

"The practice of prostitution in poverty stricken areas, just as the female vampires in Dracula's castle are; "strange ones who had survived through centuries, and who had been strengthened by the passing of the years" (358).

Dracula's brides' sexual deviation from the Victorian gender norms has been analyzed by multiple scholars; however, little attention has been paid to their surroundings as symptomatic of their transgression from their respective gender roles. I suggest their suite is an indication of their decline from the feminine domestic sphere. Contrary to their assertive sexuality, their lack of action and involvement in the duties associated with the home represents the fear associated with women endeavoring outside of the home.

On November 28, 1866 "The True Young Lady," published in Bow Bells: A Magazine of General Literature and Art for Family Reading placed domestic upkeep at the top of five "distinct heads" of skills important for respectable women; "In the first place, let not her, who aspires to the distinction of a lady, affect to spurn or really neglect household duties" (428). Again on April 10, 1867 the same publication placed the maintenance of the home as the woman's primary, and most important, task. the article "The Etiquette and Courtship of Marriage" prescribed "the wife must always have one thought uppermost in her mind, ---namely, to render her husband's home as comfortable, cheerful, and happy as possible" (246).

The female vampires in Dracula take a step away from traditional Victorian gender values. Their assertiveness is indicative of society's anxieties toward the New Woman's pursuit of equality in economic opportunities. Highlighting the limited employment opportunities for Victorian women that led to women's continued subjugation by men; Dracula's brides embody anxieties with the progression of women's role, independence in society, and the impact on the domestic lives of English families.

In the eighth chapter of The Victorian Gothic: An Edinburgh Companion titled "The Victorian Gothic and Gender" Carol Margaret Davison concludes: "Labeled by one writer as a 'sublimated Frankenstein's monster', the New Woman called into question the established idea of an essential female nature, women's limited professional and employment opportunities, and their right of choice in relation to marriage, maternity, and sexuality" (138).

While in the female vampires' room Johnathan Harker describes "in old times possibly some fair lady sat to pen, with much thought and many blushes, her ill-spelt love" (36). The fair lady that blushes while writing an affectionate letter is gone. Women no longer passively remain in their domestic range waiting coyly for men to open opportunities for them. The New Woman desires to leave her domestic sphere in favor of the society in which she has been kept from. The first dynamic to fall to the wayside; the upkeep of the home; the de-gendering of England's women leaves the domestic sphere wanting attention; as Jonathan Harker describes Dracula's brides' quarters exhibit: "The windows were curtainless, and the yellow moonlight, flooding in through the diamond panes, enabled one to see even colours, whilst it softened the wealth of dust which lay over all and disguised in some measure the ravages of time and moth" (36). The un-kept domestic surroundings is an indication of an abandoned female presence; the management of the household is the primary responsibility of the woman; maintaining a place of respite from the social sphere. The accumulation of the dust is not important and thus ignored by the progressive New Woman.

The female vampires have abandoned their sphere as domestic slaves in exchange for progressive members of the social sphere. While in the female vampires' room Johnathan Harker describes the emotional setting of their suite; 
A dread loneliness in the place which chilled my heart and made my nerves tremble. . . in old times possibly some fair lady sat to pen ... unless my senses deceive me, the old centuries had, and have, powers of their own which mere "modernity cannot kill”. (36)

Past women who adhered to feminine gender codes maintained a comforting and inviting domestic setting; the progression of the New Woman venturing outside the home leads to negligence and upsets the Victorian man's ideal household.

Victorian era England women's gender roles were in a state of turbulence; women struggled to gain an equal footing with men for employment outside the home while male society was apprehensive about the outcome on their domestic comfort. Through Dracula's brides Bram Stoker highlights the negative implications of social gender norms upon women. By restricting women's employment opportunities, maintaining dependence on men, and limiting education, women were more vulnerable to being forced in to compromising occupations; most commonly prostitution. Bram Stoker uses Dracula's brides' circumscribed range to mirror the narrow prospects for women to evolve outside of their financial gender roles. Initially an act of protection, women's singular role as domestic coordinator became a blockade to social equality. By emphasizing the neglect to the female vampires' suite Stoker outlines Victorian males' apprehension toward deviating from separate sphere ideology and the result on their domestic tranquility.

\section{REFERENCES}

[1] Byrrne, E. Fairfax. "Women and Their Sphere." Our Corner, vol. 11, Jan. 1888, pp. 5-13. ProQuest, search-proquestcom.ezproxy.uttyler.edu/pqdtglobal/docview/3792179/ fulltextPDF/5F0A664DF9094AE5PQ/6?accountid=71 23.

[2] Chambers, Robert. "Help to the Fallen." Chambers's Journal of Popular Literature, Science and

Arts, Jan. 1854-Nov. 1897, Edited by William Chambers, no. 267, 12 Feb. 1859, pp. 111112. ProQuest,

ezproxy.uttyler.edu/login?url=https://search-proquestcom.ezproxy.uttyler.edu/docview/2576640?accountid $=7123$.

[3] Davison, Carol Margaret. "The Victorian Gothic and Gender." The Victorian Gothic: An

Edinburgh Companion, edited by Andrew Smith and William Hughes, Edinburgh University Press, 2012, pp.

124-141. JSTOR, www.jstor.org/stable/10.3366/j.ctt3fgt3w.12.

[4] Haldane, R B. "On Some Economic Aspects of Women's Suffrage." The Contemporary Review, 18661900, vol. 58, Dec. 1890, pp. 830-838.ProQuest, ezproxy.uttyler.edu/login?url=https://search-proquestcom.ezproxy.uttyler.edu/docview/6659568?accountid $=7123$.

[5] Ipsen, Carl. "Work, Gender, and Family in Victorian England." Victorian Studies; Bloomington, vol. 40, no. 3, 1997, pp. 547-549. ProQuest, ezproxy.uttyler.edu/login?url=https://search-proquestcom.ezproxy.uttyler.edu/docview/211999133?accounti $\mathrm{d}=7123$.

[6] Macilwee, Michael. "Prostitution." The Liverpool Underworld: Crime in the City, 1750-1900, 1st ed., Liverpool University Press, 2011, pp. 253271. JSTOR, www.jstor.org/stable/j.ctt5vj9vv.25.

[7] Prescott, Charles E., and Grace A. Giorgio. "Vampiric Affinities: Mina Harker And The Paradox Of Femininity In Bram Stokers Dracula." Victorian Literature and Culture, vol. 33, no. 02, Sept. 2005, pp. 487-515. JSTOR, doi:10.1017/s1060150305050953.

[8] Schwartz, Laura. "Feminist thinking on education in Victorian England." Oxford Review of Education, vol. 37, no. 5, 2011, pp. 669-682. ProQuest, doi:10.1080/03054985.2011.621684.

[9] Stoker, Bram. Dracula. Canterbury Classics, 2012.

[10] Swartz-Levine, Jennifer A. "Staking Salvation: The Reclamation of the Monstrous Female in Dracula." Midwest Quarterly, vol. 57, no. 4, Summer 2016, pp. 345-361. EBSCOhost,

ezproxy.uttyler.edu/login?url=http://search.ebscohost.c om/login.aspx direct=true \&db=hft\&AN=117002243\& site $=$ ehost-live $\&$ scope $=$ site

[11] "The Etiquette of Courtship and Marriage." Bow Bells: A Magazine of General Literature and Art for Family Reading, vol. 6, no. 141, 10 Apr. 1867, p. 246. ProQuest,

ezproxy.uttyler.edu/login?url=https://search-proquestcom.ezproxy.uttyler.edu/docview/3106723?accountid $=7123$.

[12] "The True Young Lady." Bow Bells: A Magazine of General Literature and Art for Family Reading, vol. 5, no. 122, 28 Nov. 1866, p. 428. ProQuest, ezproxy.uttyler.edu/login?url=https://search-proquestcom.ezproxy.uttyler.edu/docview/3130266?accountid $=7123$. 